\begin{tabular}{|c|c|c|}
\hline BIODIK & $\begin{array}{l}\text { BIODIK: Jurnal IImiah Pendidikan Biologi } \\
\text { ISSN 2580-0922 (online), ISSN 2460-2612 (print) } \\
\text { Volume 07, Nomor 03, Tahun 2021, Hal. 56-67 } \\
\text { Available online at: } \\
\text { https://online-journal.unja.ac.id/biodik }\end{array}$ & BIODIK \\
\hline
\end{tabular}

Research Article

open access

\title{
Analisis Komponen Penyusun Desain Kegiatan Laboratorium Berbasis Keterampilan Proses Sains Pada Materi Kerja Enzim Katalase
}

\section{(Analysis of the components Designing Laboratory Activities based on science process skills of the Working of Catalyst Enzyme)}

\author{
Laurina Sinurat*, Bambang Supriatno, Sri Anggraeni \\ Universitas Pendidikan Indonesia \\ JI. Dr. Setiabudhi No. 229, Cidadap, Isola, Sukasari, Kota Bandung, Jawa Barat 40154-Indonesia \\ ${ }^{*}$ Corresponding Author : laurinasinurat@gmail.com
}

\begin{tabular}{|c|c|}
\hline Informasi Artikel & $\overline{\text { ABSTRACT }}$ \\
\hline $\begin{array}{l}\text { Submit: } 01-06-2021 \\
\text { Diterima: } 15-08-2021 \\
\text { Dipublikasikan: } 25-09-2021\end{array}$ & $\begin{array}{l}\text { One of the objectives of learning biology is to give students experience in the } \\
\text { scientific method which is the demand of the 21st century. This ability is a } \\
\text { science process skill that can be obtained in laboratory activities. So that the } \\
\text { design of laboratory activities should lead to science process skills. This study } \\
\text { aims to analyze the design of laboratory activities to find out: 1) the relevance of } \\
\text { competence and content to basic competencies, 2) what competencies or } \\
\text { abilities are built in the practicum, 3) tools, materials according to school } \\
\text { standards and work procedures are well structured or not., 4) the knowledge } \\
\text { gained whether the focus is on the main thing or not. This study uses a qualitative } \\
\text { descriptive method with the ANCOR stages, namely analysis, testing and } \\
\text { reconstruction of five designs of laboratory activities on the working material of } \\
\text { the catalase enzyme. The results of the study indicate that the lack of } \\
\text { competence in science process skills built on the five designs of laboratory } \\
\text { activities is proven based on the results of the analysis on the acquisition of } \\
\text { knowledge is still lacking. Therefore, knowledge reconstruction needs to be } \\
\text { carried out on the design of laboratory activities to improve the quality of } \\
\text { laboratory activities in accordance with the demands of basic competencies. } \\
\text { Key words: design of laboratory activities,science process skills, working of } \\
\text { catalase enzymes }\end{array}$ \\
\hline Penerbit & ABSTRAK \\
\hline $\begin{array}{l}\text { Program Studi Pendidikan Biologi } \\
\text { FKIP Universitas Jambi, } \\
\text { Jambi- Indonesia }\end{array}$ & $\begin{array}{l}\text { Salah satu tujuan pembelajaran biologi yaitu memberi pengalaman kepada } \\
\text { siswa pada metode ilmiah yang merupakan tuntutan abad } 21 \text {. Kemampuan } \\
\text { tersebut merupakan keterampilan proses sains yang bisa didapatkan dalam } \\
\text { kegiatan laboratorium. Sehingga desain kegiatan laboratorium sebaiknya } \\
\text { mengarah kepada keterampilan proses sains. penelitian ini bertujuan untuk } \\
\text { menganalisis desain kegiatan laboratorium untuk mengetahui : 1) relevansi } \\
\text { kompetensi dan konten terhadap kompetensi dasar, 2) kompetensi atau } \\
\text { kemampuan yang seperti apa yang dibangun dalam praktikum, 3) alat, bahan } \\
\text { sesuai standar sekolah serta prosedur kerja terstruktur dengan baik atau tidak, } \\
\text { 4) pengetahuan yang diperoleh apakah fokus kepada hal utama atau tidak. } \\
\text { Penelitian ini menggunakan metode deskriptif kualitatif dengan tahapan ANCOR } \\
\text { yaitu analisis, uji coba dan rekonstruksi lima desain kegiatan laboratorium pada } \\
\text { materi kerja enzim katalase. Hasil dari penelitian menunjukkan bahwa } \\
\text { kurangnya kompetensi keterampilan proses sains yang dibangun pada kelima } \\
\text { desain kegiatan laboratorium dibuktikan berdasar hasil analisis pada perolehan } \\
\text { pengetahuan masih kurang. Oleh karena itu rekonstruksi pengetahuan perlu } \\
\text { dilakukan pada desain kegiatan laboratorium untuk meningkatkan kualitas } \\
\text { kegiatan laboratorium yang sesuai dengan tuntutan kompetensi dasar. }\end{array}$ \\
\hline
\end{tabular}


This BIODIK : Jurnal IImiah Pendidikan Biologi is licensed under a CC BY-NC-SA (Creative Commons Attribution-ShareAlike 4.0 International License)

\section{PENDAHULUAN}

Biologi merupakan ilmu yang mempelajari tentang bagaimana peserta didik untuk mencari tahu tentang lingkungannya secara sistematis dan berkembang dari serangkaian metode ilmiah sehingga dalam meningkatkan perkembangan peserta didik, pembelajaran biologi berorientasi terhadap penguasaan pengetahuan, konsep sains serta penguasaan sikap sains yang harus dimiliki oleh siswa (Astuti et al., 2019). Salah satu tujuan pembelajaran biologi menurut Permendikbud No.36 Tahun 2018 yaitu memberi pengalaman kepada siswa pada metode ilmiah dan aspek keselamatan kerja dengan mempraktekkan metode ilmiah melalui pengamatan dan percobaan atau eksperimen, siswa dapat melakukan pengujian hipotesis dengan merancang eksperimen, mengolah data serta mengkomunikasikan hasil eksperimen yang merupakan tuntutan dalam abad 21. Sejalan dengan Koirala, (2019) yang mengatakan bahwa kegiatan laboratorium mampu membantu peserta didik dalam memahami konsep ilmiah dengan jelas dan meningkatkan hasil belajar siswa.

Biologi merupakan salah satu bidang sains menyediakan berbagai pengalaman belajar untuk memahami produk serta proses sains yang disatukan dalam keterampilan proses sains karena keterampilan proses sains mengarah pada kognitif dan psikomotor yaitu menemukan suatu konsep, prinsip atau teori untuk mengembangkan konsep yang ada sebelumnya, melakukan penyangkalan terhadap penemuan, serta prinsip dan teori yang sudah diterima kebenarannya (Sasanti et al., 2017). Cara meningkatkan kualitas pendidikan sesuai kurikulum yang berlaku yakni dengan menitikberatkan kegiatan pembelajaran pada aktivitas peserta didik yaitu melalui kegiatan praktikum yang merupakan strategi yang mengarahkan peserta didik untuk menemukan suatu pengetahuan dari konsep-konsep yang diperoleh dari pengalaman langsung dalam mengamati suatu objek atau fenomena (Aisya et al., 2016). Di dalam pelajaran IPA, berkaitan dengan proses pencarian tentang suatu hal secara sistematis dan sesuai dengan hasil penemuan, bukan hanya sekedar pelajaran yang di dalamnya berisi tentang penguasaan konsep, prinsip, atau penguasaan kumpulan pengetahuan berupa fakta-fakta, di dalam IPA dikenal dengan suatu proses penemuan (Nisa, 2017). Dengan mengembangkan keterampilan seperti ilmu yang didapatkan dari proses, peserta didik mampu menemukan dan mengembangkan fakta dan konsep serta menumbuhkan dan mengembangkan sikap dan nilai yang di tuntut (Laila Puspita, 2019).

Keterampilan dasar yang terkandung pada keterampilan proses sains merupakan keterampilan yang diperlukan oleh seseorang untuk melakukan penyelidikan ilmiah, sehingga memudahkan seseorang untuk memahami peristiwa yang terjadi (Septaria et al., 2019). Keterampilan dasar yang diperlukan oleh seseorang masih belum dilatihkan secara maksimal di berbagai jenjang Pendidikan di Indonesia, di jenjang sekolah menengah atas yang dapat dilakukan pada praktikum masih kurang teliti dalam mengamati, menyelesaikan permasalahan yang belum dipahami, dan bagaimana petunjuk dari sebuah praktikum (Septaria et al., 2019). Keterampilan proses sains adalah suatu keterampilan seseorang dalam menggunakan pikiran, nalar dan perbuatan secara efektif dan efisien untuk mencapai suatu hasil tertentu (Elvanisi et al., 2018). Keterampilan dasar dalam keterampilan proses sains meliputi : 1) mengamati, 2) menyusun hipotesis, 3) merumuskan masalah, 4) mengidentifikasi variabel, 5) mengkomunikasikan data dan 6) menyimpulkan data (Mirawati \& Royani, 2019). Penelitian Elvanisi et al.,(2018) mengatakan bahwa persentase keterampilan proses sains yang dikuasai oleh siswa SMA se-Kecamatan Bukit Kecil 
Palembang yaitu indikator tertinggi meramalkan sebesar $73,48 \%$ dan indikator terendah merumuskan hipotesis $42,04 \%$. Persentase keterampilan proses sains yang dikuasai oleh siswa SMA se-Kecamatan Ilir Barat I Palembang yaitu indikator tertinggi mengelompokkan sebesar $77,21 \%$ dan indikator yang terendah mengkomunikasikan sebesar 49,03\% sehingga ini membuktikan bahwa keterampilan proses sains pada tingkat SMA masih rendah (Elvanisi et al., 2018). Melalui praktikum siswa diberi kesempatan untuk mengalami sendiri, melaksanakan suatu proses, mengikuti suatu objek, menganalisis, membuktikan dan menarik kesimpulan sendiri mengenai suatu objek, keadaan atau proses tertentu. Dengan demikian, siswa akan lebih yakin atas suatu hal dari pada hanya menerima informasi yang diberikan guru dan buku (Alexander et al., 2018). Namun kebanyakan kegiatan laboratorium dilakukan secara tradisional yaitu siswa mengikuti langkah kerja yang ditentukan, kemudian siswa membuat laporan untuk melaporkan hasil praktikumnya. Hal tersebut tidak efektif untuk meningkatkan proses ilmiah siswa. Sehingga diperlukan kegiatan praktikum yang membuat siswa dapat belajar mandiri dan efisien sehingga tujuan praktikum dapat tercapat (Laelasari et al., 2019).

Berdasarkan hal tersebut maka peneliti mencoba merancang kegiatan laboratorium berbasis keterampilan proses sains yang melibatkan siswa untuk mengembangkan keterampilan percobaan atau eksperimen, pengujian hipotesis dengan merancang eksperimen, mengolah data serta mengkomunikasikan hasil eksperimen. Kegiatan laboratorium pada materi kerja enzim katalase merupakan topik yang diberikan pada siswa kelas XII SMA. Praktikum pada materi ini menuntut siswa untuk memahami bagaimana sifat-sifat enzim, faktor-faktor apa saja yang mempengaruhi kerja enzim katalase. Oleh karena itu desain kegiatan laboratorium yang mampu membentuk konsep-konsep esensial yang dapat mencapai tujuan pembelajaran dan relevan terhadap tuntutan kompetensi dasar. Analisis desain kegiatan laboratorium bertujuan untuk mengetahui : 1) gambaran relevansi kompetensi dan konten terhadap kompetensi dasar, 2) gambaran kompetensi atau kemampuan yang seperti apa yang dibangun dalam praktikum, 3) mengetahui apakah alat, bahan sesuai standar sekolah serta prosedur kerja terstruktur dengan baik atau tidak, 4) mengetahui gambaran pengetahuan yang diperoleh apakah focus kepada hal utama atau tidak. Analisis desain kegiatan laboratorium ini dapat digunakan sebagai gambaran dalam melakukan rekonstruksi dan modifikasi desain untuk meningkatkan kualitas proses kegiatan di laboratorium pada materi kerja enzim katalase.

\section{METODE PENELITIAN}

Penelitian ini merupakan penelitian deskriptif kualitatif melalui tahapan ANCOR (Analisis, Uji Coba, dan Rekontruksi). Analisis yang dilakukan yaitu analisis terhadap kegiatan pada lembar kerja siswa atau desain kegiatan laboratorium untuk mengetahui seberapa besar kegiatan tersebut relevan dengan kurikulum yang berlaku, kompetensi apa yang dikembangkan dalam kegiatan praktikum, bagaimana komponen praktikal pada kegiatan laboratorium serta konstruksi pengetahuan siswa. Setelah menganalisis desain kegiatan laboratorium tersebut maka kita dapat mengetahui kelemahan dari desain kegiatan laboratorium. Selanjutnya desain kegiatan yang sudah dianalisis diujicobakan untuk mengetahui apakah desain kegiatan laboratorium tersebut dapat dilakukan oleh siswa atau tidak. Apabila desain kegiatan laboratorium tersebut kurang tepat atau terjadi kegagalan dalam kegiatan laboratorium maka akan dilakukan rekonstruksi untuk mengubah sebagian dari desain kegiatan.

Adapun yang menjadi objek penilitian adalah lembar kerja siswa pada praktikum kerjaa enzim katalase yang digunakan pada jenjang SMA kelas XII. Lembar kerja berasal dari buku pegangan siswa yang diterbitkan oleh beberapa penerbit di mulai dari kurikulum KTSP, kurikulum 2013 hingga kurikulum 2013 revisi atau revisi 2016. Adapun kode dari kelima DKL tersebut adalah AY dan SI untuk kurikulum 
KTSP, PE untuk kurikulum 2013, IE dan NY untuk kurikulum 2013 revisi atau revisi 2016. Penelitian ini dilakukan pada bulan April sampai dengan Mei 2021 yang dilaksanakan di FMIPA UPI.

\section{HASIL PENELITIAN DAN PEMBAHASAN}

Kegiatan laboratorium sebelum diujicobakan, perlu menganalisis DKL yang diterbitkan oleh penerbit terlebih dahulu dengan cara menganalisis beberapa aspek yaitu aspek relevansi terhadap kurikulum, aspek kompetensi, aspek praktikal dan kontruksi pengetahuan. Dalam aspek relevansi terhadap kurikulum, peneliti menganalisis bagaimana relevansi kompetensi dengan kompetensi dasar, relevansi konten dengan kompetensi dasar. Analisis relevansi ini bertujuan untuk mengetahui apakah kompetensi dalam DKL sudah relevan terhadap tuntutan kompetensi dasar dari kurikulum serta apakah konten yang dilakukan pada DKL sudah relevan terhadap kompetensi yang dituntut dari kurikulum yang berlaku. Adapun hasil analisis aspek relevansi terhadap kurikulum dari kelima DKL tersebut dapat di lihat pada tabel 1.

Tabel 1. Akumulasi Data Aspek Relevansi dengan Kurikulum

\begin{tabular}{cccc}
\hline DKL & Kompetensi dengan KD & Konten dengan KD & Rata-rata \\
\hline AY & 2 & 2 & 2 \\
SI & 2 & 1 & 1,5 \\
PE & 2 & 2 & 2 \\
IE & 2 & 2 & 2 \\
NY & 2 & 2 & 2 \\
\hline
\end{tabular}

Hasil analisis aspek relevensi dengan kurikulum menunjukan bahwa kompetensi yang dikembangkan dalam kegiatan praktikum, sudah memenuhi standar minimal Kompetensi Dasar (KD). Konten pada kegiatan praktikum, hampir seluruhnya telah memenuhi standar minimal KD. Dengan kata lain, sebagian besar kompetensi yang dikembangkan dan konten pada LKPD sudah relevan dengan kompetensi dasar yang ditentukan kurikulum. Namun pada DKL SI, konten kurang memenuhi kurikulum karena hanya melakukan satu perlakuan sedangkan seharusnya ketika ingin mengetahui factor yang mempengaruhi kerja enzim, perlakuan harus dilakukan lebih dari satu perlakuan.

Dalam aspek kompetensi, peneliti menganalisis bagaimana kompetensi yang dibangun pada praktikum tersebut, misalnya kemampuan observasi, representasi data,interpretasi data serta bagaimana level kemampuan berpikir yang ada dalam DKL tersebut. Analisis kompetensi ini bertujuan untuk mengetahui seperti apa kemampuan yang tertuang dalam DKL. Adapun hasil analisis aspek kompetensi dari kelima DKL tersebut dapat di lihat pada tabel 2.

Tabel 2. Akumulasi Data Aspek Kompetensi

\begin{tabular}{ccccc}
\hline DKL & Kemampuan Observasi & Representasi & Interpretasi & $\begin{array}{c}\text { Level Kemampuan } \\
\text { Berpikir }\end{array}$ \\
\hline AY & 2 & 2 & 1 & 1 \\
SI & 2 & 2 & 2 & 1 \\
PE & 2 & 3 & 2 & 1 \\
IE & 3 & 3 & 2 & 2 \\
NY & 3 & 2 & 2 & 1 \\
$\overline{\mathbf{X}}$ & 2,4 & 3,4 & 1,8 & 1,2 \\
\hline
\end{tabular}

Hasil analisis aspek kompetensi menunjukan bahwa pada sebagian besar DKL yang digunakan, peserta didik hanya mampu mengobservasi karakter umum dari objek/fenomena. Namun pada DKL tertentu misalnya DKL IE, peserta didik mampu mengobservasi karakter spesifik dari objek/fenomena, bahkan kemampuan observasi peserta didik dapat mendukung perolehan pengetahuannya seperti 
kegiatan yang terdapat pada DKL NY. Hampir seluruh DKL, data hasil pengamatan/observasi direpresentasikan kedalam bentuk lain dengan yaitu data hasil observasi direpresentasikan ke dalam bentuk standar seperti tabel pengamatan. Hampir seluruh DKL menggunakan komponen data secara keseluruhan dalam proses interpretasi, kecuali pada DKL SI yang hanya menggunakan beberapa komponen data dalam proses interpretasi. Hampir seluruh kegiatan prkatikum hanya melibatkan kemampuan berpikir level C1 hingga C3 (LOTS), kecuali pada DKL IE yaitu kegiatan praktikum telah mengembangkan kemampuan berpikir hingga level Menganalisis (C4).

Dalam aspek praktikal, peneliti menganalisis bagaimana kesesuaian alat praktikum dengan standar sekolah, kesesuaian bahan praktikum dengan keperluan kegiatan serta struktur kerja praktikum. Analisis praktikal ini bertujuan untuk mengetahui apakah alat dan bahan yang digunakan dalam praktikum tersedia di sekolah sesuai standar, apakah struktur kerja praktikum mudah dipahami dan dilakukan atau justru menyulitkan siswa dalam mengerjakan. Adapun hasil analisis aspek praktikal dari kelima DKL tersebut dapat di lihat pada tabel 3 .

Tabel 3. Akumulasi Data Aspek Praktikal

\begin{tabular}{cccc}
\hline DKL & $\begin{array}{c}\text { Kesusaian Alat Praktikum } \\
\text { dengan Standar Sekolah }\end{array}$ & $\begin{array}{c}\text { Kesesuaian Bahan } \\
\text { dengan Keperluan } \\
\text { Kegiatan }\end{array}$ & Struktur Kerja Praktikum \\
\hline AY & 4 & 2 & 3 \\
SI & 4 & 2 & 3 \\
PE & 4 & 2 & 4 \\
IE & 4 & 2 & 3 \\
NY & 4 & 2 & 3,2 \\
\hline$\overline{\mathbf{X}}$ & 4 & 2 & 3 \\
\hline
\end{tabular}

Hasil analisis aspek kompetensi menunjukan bahwa seluruh alat yang digunakan pada praktikum di DKL dapat ditemukan di laboratorium sekolah dengan standar sekolah, namun pada bahan praktikum yang diperlukan sebagian besar DKL terdapat bahan yang harus disediakan dari luar sekolah seperti bahan utama hati ayam yang tidak bias disediakan dari sekolah. Pada struktur kerja praktikum, sebagian DKL memiliki struktur kerja yang sudah berurut dengan jelas namun ada prosedur kerja yang masih rancu dalam tatanan Bahasa sehingga berkemungkinan berpengaruh pada hasil pengamatan yang akan di peroleh.

Dalam aspek rekonstruksi pengetahuan, peneliti menganalisis judul/tujuan serta pertanyaan fokus, objek fenomena, teori, prinsip dan konsep, perekaman dan transformasi data serta perolehan pengetahuan. Analisis rekonstruksi pengetahuan ini bertujuan untuk mengetahui apakah terdapat judul, tujuan serta pertanyaan fokus, objek fenomena yang seperti apa yang diamati, apakah ada teori, prinsip dan konsep yang dibangun, bagaimana perekaman serta transformasi data dan bagaimana perolehan pengetahuan dalam DKL tersebut. 
Adapun hasil analisis aspek rekonstruksi pengetahuan dari kelima DKL tersebut dapat di lihat pada tabel 4.

Tabel 4. Akumulasi Data Aspek Rekonstruksi Pengetahuan

\begin{tabular}{cccccc}
\hline DKL & $\begin{array}{c}\text { Judul/Tujuan dan } \\
\text { Pertanyaan Fokus }\end{array}$ & Objek Fenomena & $\begin{array}{c}\text { Teori Prinsip dan } \\
\text { Konsep }\end{array}$ & $\begin{array}{c}\text { Perekaman } \\
\text { dan } \\
\text { Transformasi } \\
\text { data }\end{array}$ & $\begin{array}{c}\text { Perolehan } \\
\text { Pengetahuan }\end{array}$ \\
\hline AY & 1 & 1 & 2 & 3 & 2 \\
SI & 1 & 1 & 1 & 3 & 2 \\
PE & 3 & 2 & 2 & 4 & 3 \\
IE & 4 & 2 & 3 & 4 & 3 \\
NY & 3 & 2 & 2 & 4 & 2,6 \\
$\overline{\mathbf{X}}$ & 2,4 & 1,6 & 2 & 3,6 & 3 \\
\hline
\end{tabular}

Hasil analisis aspek rekonstruksi pengetahuan menunjukan bahwa hampir seluruh DKL sudah terdapat judul/tujuan/pertanyaan fokus, tetapi terdapat DKL AY dan SI tidak memfokuskan kepada hal utama yang berkaitan dengan objek dan peristiwa atau tidak mengandung bagian konseptual terutama prinsip. Hampir seluruh DKL terdapat peristiwa dan objek dapat diidentifikasi dan konsisten dengan pertanyaan fokus, kecuali pada DKL AY dan SI yaitu terdapat peristiwa yang tidak konsisten dengan pertanyaan fokus. Sebagian DKL mencakup sedikit konsep yang dapat diidentifikasi, tetapi tanpa prinsipprinsip serta teori, atau sebuah prinsip yang tertulis merupakan pengetahuan yang diperoleh dari kegiatan laboratorium. Namun terdapat beberapa DKL yaitu DKL IE mencakup konsep-konsep dan kurang lebih satu prinsip (konseptual atau metodologi) atau konsep-konsep dan sebuah teori yang relevan dapat diidentifikasi.

Kegiatan pencatatan pada sebagian DKL dapat diidentifikasi, konsisten dengan pertanyaan utama atau kegiatan utama. Namun pada beberapa DKL seperti DKL AY dan SI, kegiatan pencatatan atau transformasi atau peristiwa tidak konsisten. Sebagian DKL, perolehan pengetahuan tidak konsisten dengan data dan atau peristiwa yang dicatat dan ditransformasikan atau perolehan pengetahuan sudah mengandung sisi konseptual. Sementara sebagian besar, perolehan pengetahuan mengandung konsepkonsep yang sesuai dengan pertanyaan fokus dan sesuai dengan hasil pencatatan dan transformasi.

Tujuan, pendekatan, prosedur serta materi dalam suatu desain kegiatan laboratorium seharusnya memperhatikan beberapa hal berikut : 1) tujuan dari kegiatan laboratorium tidak hanya menekankan pada aspek kognitif melainkan juga pada aspek psikomotorik yang bertujuan untuk mengembangkan keterampilan dasar laboratorium. 2) penggunaan pendekatan deduktif dengan model ekspositori hanya dapat melatih keterampilan manipulasi dan mengumpulkan data, tidak dapat digunakan untuk merancang eksperimen. 3) pada aspek prosedur kerja, siswa seharusnya diberikan kesempatan untuk merancang kegiatan seperti memanipulasi variabel. 4) pada aspek materi, kegiatan laboratorium yang dikembangkan seharunya mempertimbangkan essensi, kesesuaian, kedalaman serta kompleksitasnya. Sejalan dengan Hasil penelitian Royani et al., (2018) menunjukkan keterampilan proses sains siswa mengalami peningkatan dan secara signifikan berbeda nyata dengan keterampilan proses sains siswa yang dibelajarkan menggunakan pembelajaran konvensional. Hasil penelitian tersebut hanya mengujicobakan pembelajaran langsung berbasis praktikum tanpa mengembangkan LKS. Salah satu penyebab kurang bermaknanya suatu praktikum adalah desain kegiatan laboratorium tidak dapat menjadi petunjuk yang tepat untuk mengkonstruk konsep, prinsip dan teori serta kurang melibatkan proses berpikir seperti keterampilan proses sains siswa. Oleh karena itu, agar kegiatan laboratorium menjadi lebih efektif dan bermakna, maka guru perlu menganalisis terlebih dahulu penerapan kelayakan suatu desain kegiatan 
laboratorium dan menguji coba DKL sehingga dapat mengadaptasi serta merekonstruksi sebelum mengadaptasi desain kegiatan laboratorium.

\section{Rekonstruksi LKS \\ Lembar Kegiatan Pratikum}

\section{Kompetensi Dasar}

3.2 Menjelaskan proses metabolisme sebagai reaksi enzimatis dalam makhluk hidup.

4.2 Menyusun laporan hasil percobaan tentang mekanisme kerja enzim, fotosintesis, dan respirasi anaerob.

\section{Tujuan}

1. Mengamati faktor - faktor yang mempengaruhi kerja enzim katalase

2. Menganalisis peranan enzim katalase

3. Menganalisis reaksi - reaksi kimia yang terjadi pada pengujian enzim katalase

\section{Teori}

Enzim adalah suatu protein yang berperan sebagai katalis dalam metabolisme makhluk hidup yang berperan untuk mempercepat reaksi kimia yang terjadi di dalam tubuh makhluk hidup, tetapi enzim itu sendiri tidak ikut bereaksi sehingga disebut sebagai salah satu katalisator alami.

Enzim katalase adalah salah satu jenis enzim yang umum ditemui didalam sel - sel makhluk hidup. Enzim katalase berfungsi untuk merombak Hidrogen Peroksida $\left(\mathrm{H}_{2} \mathrm{O}_{2}\right)$ yang bersifat racun yang merupakan sisa/hasil sampingan dari proses metabolisme.

Apabila $\mathrm{H}_{2} \mathrm{O}_{2}$ tidak diuraikan dengan enzim ini, maka akan menyebabkan kematian pada sel - sel. Oleh sebab itu, enzim katalase untuk merombak $\mathrm{H}_{2} \mathrm{O}_{2}$ menjadi substansi yang tidak berbahaya, yaitu berupa air dan oksigen. Selain bekerja secara spesifik pada substrat tertentu, enzim juga bersifat termolabil (rentan terhadap perubahan suhu) serta merupakan suatu senyawa golongan protein. Pengaruh temperatur terlihat sangat jelas, karena dapat merusak enzim dan membuatnya terdenaturasi seperti kebanyakan protein.

\section{Alat dan Bahan}

Alat :

\begin{tabular}{|l|l|c|l|l|c|}
\hline No & \multicolumn{1}{|c|}{ Nama } & Jumlah & No & \multicolumn{1}{|c|}{ Nama } & Jumlah \\
\hline 1 & Tabung reaksi & 15 buah & 11 & Kaki tiga & 1 buah \\
\hline 2 & Rak tabung reaksi & 3 buah & 12 & Lampu spiritus & 1 buah \\
\hline 3 & Pipet tetes & 5 buah & 13 & Penjepit tabung & 1 buah \\
\hline 4 & Gelas ukur & 5 buah & 14 & Lumpang \& alu & 1 buah \\
\hline 5 & Gelas kimia $100 \mathrm{ml}$ & 1 buah & 15 & Spatula & 1 buah \\
\hline 6 & Korek api & 5 buah & 16 & Pisau cutter & 1 buah \\
\hline 7 & Pinset & 1 buah & 17 & Kertas label & 15 buah \\
\hline 8 & Penggaris & 1 buah & 18 & Termometer & 5 buah \\
\hline 9 & Kertas saring & 10 lembar & 19 & Corong & 5 buah \\
\hline 10 & Kertas pH & 5 lembar & & & \\
\hline
\end{tabular}


Bahan :

\begin{tabular}{|l|l|c|}
\hline No & \multicolumn{1}{|c|}{ Nama } & Jumlah \\
\hline 1 & Hati ayam segar & 6 buah \\
\hline 2 & Hati ayam yang sudah dibiarkan 12 jam & 1 buah \\
\hline 3 & Hati ayam yang sudah dibiarkan 24 jam & 1 buah \\
\hline 4 & Larutan Hidrogen Peroksida $\left(\mathrm{H}_{2} \mathrm{O}_{2}\right) 3 \%$ & $50 \mathrm{ml}$ \\
\hline 5 & Larutan Natrium Hidroksida $(\mathrm{NaOH}) 0,1 \mathrm{M}$ & $50 \mathrm{ml}$ \\
\hline 6 & Larutan Natrium Hidroksida $(\mathrm{NaOH}) 0,01 \mathrm{M}$ & $50 \mathrm{ml}$ \\
\hline 7 & Larutan Asam Klorida $(\mathrm{HCl}) 0,1 \mathrm{M}$ & $50 \mathrm{ml}$ \\
\hline 8 & Larutan Asam Klorida $(\mathrm{HCl}) 0,01 \mathrm{M}$ & $50 \mathrm{ml}$ \\
\hline 9 & Aquades & $100 \mathrm{ml}$ \\
\hline 10 & Es batu & 1 buah $(100 \mathrm{ml})$ \\
\hline
\end{tabular}

\section{Posedur Kerja}

\section{Indikator 1:}

1. Sediakan 5 buah tabung reaksi dan berilah penanda dengan label $1,2,3,4$, dan 5 .

2. Potonglah hati segar menggunakan cutter dengan ukuran $1 \mathrm{~cm} \times 1 \mathrm{~cm}$ sebanyak 3 potong.

3. Potongan yang pertama giling dengan lumping hingga hancur, kemudian letakkan di tabung reaksi 1 kemudian dorong dengan menggunakan spatula agar hati berada di dasar tabung reaksi.

4. Rebuslah potongan hati kedua dengan menggunakan gelas kimia $100 \mathrm{ml}$ yang telah berisi $50 \mathrm{ml}$ aquades dan biarkan hingga 5 menit di atas pembakar spiritus lalu angkat dengan menggunakan pinset dan dinginkan.

5. Setelah dingin, giling dengan lumpang hingga hancur, masukkan hati ke dalam tabung reaksi 2 dengan menggunakan pinset, kemudian dorong dengan menggunakan spatula agar hati berada di dasar tabung reaksi.

6. Rebuslah potongan hati ketiga dengan menggunakan gelas kimia $100 \mathrm{ml}$ yang telah berisi $50 \mathrm{ml}$ aquades dan biarkan hingga 15 menit di atas pembakar spiritus lalu angkat dengan menggunakan pinset dan dinginkan.

7. Setelah dingin, giling dengan lumpang hingga hancur, masukkan hati ke dalam tabung reaksi 3 dengan menggunakan pinset, kemudian dorong dengan menggunakan spatula agar hati berada di dasar tabung reaksi.

8. Masukkan hati yang telah dibiarkan selama 12 jam ke dalam lumpang dan giling hingga hancur kemudian masukkan ke dalam tabung raksi 4 dengan ukuran yang sama besar dengan potongan hati yang lain.

9. Masukkan hati yang telah dibiarkan selama 24 jam ke dalam lumpang dan giling hingga hancur kemudian masukkan ke dalam tabung raksi 5 dengan ukuran yang sama besar dengan potongan hati yang lain.

10. Masukkan $\mathrm{H}_{2} \mathrm{O}_{2} 3 \%$ ke dalam masing-masing tabung reaksi sebanyak 15 tetes dengan menggunakan pipet tetes secara bersamaan, kemudian ukur tinggi gelembung semua tabung reaksi dalam jangka waktu 2 menit, kemudian catat pada data eksperimen. 


\section{Indikator 2 :}

11. Sediakan 5 buah tabung reaksi dan berilah penanda dengan label 1, 2, 3, 4, dan 5 .

12. Potonglah hati segar menggunakan cutter untuk mempermudah penghancuran, kemudian giling dengan menggunakan lumpang hingga hati tersebut hancur, kemudian saring dengan menggunakan kertas saring dan corong sehingga menghasilkan ekstrak hati.

13. Masukkan ekstrak hati ke dalam semua tabung reaksi 1 sampai 5 dengan menggunakan pipet tetes sebanyak 20 tetes/tabung reaksi.

14. Sediakan air es yang bersuhu $10 \mathrm{C}$ (gunakan termometer untuk mengetahui suhunya) di dalam gelas ukur sebanyak $50 \mathrm{ml}$ dan letakkan tabung 1 ke dalam gelas ukur tersebut.

15. Sediakan air es yang bersuhu $20 \mathrm{C}$ (gunakan termometer untuk mengetahui suhunya) di dalam gelas ukur sebanyak $50 \mathrm{ml}$ dan letakkan tabung 2 ke dalam gelas ukur tersebut.

16. Sediakan air es yang bersuhu $30 \mathrm{C}$ (gunakan termometer untuk mengetahui suhunya) di dalam gelas ukur sebanyak $50 \mathrm{ml}$ dan letakkan tabung 3 ke dalam gelas ukur tersebut.

17. Sediakan air es yang bersuhu $40 \mathrm{C}$ (gunakan termometer untuk mengetahui suhunya) di dalam gelas ukur sebanyak $50 \mathrm{ml}$ dan letakkan tabung 4 ke dalam gelas ukur tersebut.

18. Sediakan air es yang bersuhu $50 \mathrm{C}$ (gunakan termometer untuk mengetahui suhunya) di dalam gelas ukur sebanyak $50 \mathrm{ml}$ dan letakkan tabung 5 ke dalam gelas ukur tersebut.

19. Masukkan $\mathrm{H}_{2} \mathrm{O}_{2} 3 \%$ ke dalam masing-masing tabung reaksi sebanyak 15 tetes secara bersamaan, kemudian ukur tinggi gelembung semua tabung reaksi dalam jangka waktu 2 menit, kemudian catat pada data eksperimen.

\section{Indikator 3 :}

20. Sediakan 5 buah tabung reaksi dan berilah penanda dengan label 1, 2, 3, 4, dan 5 .

21. Potonglah hati segar menggunakan cutter untuk mempermudah penghancuran, kemudian giling dengan menggunakan lumpang hingga hati tersebut hancur, kemudian saring dengan menggunakan kertas saring dan corong sehingga menghasilkan ekstrak hati.

22. Masukkan ekstrak hati ke dalam semua tabung reaksi 1 sampai 5 dengan menggunakan pipet tetes sebanyak 20 tetes/tabung reaksi.

23. Masukkan $\mathrm{HCl}(0,1 \mathrm{M})$ ke dalam tabung reaksi 1 sebanyak 10 tetes dengan menggunakan pipet tetes kemudian hitung $\mathrm{pH}$ larutan dengan menggunakan kertas $\mathrm{pH}$.

24. Masukkan $\mathrm{HCl}(0,01 \mathrm{M})$ ke dalam tabung reaksi 2 sebanyak 10 tetes dengan menggunakan pipet tetes kemudian hitung $\mathrm{pH}$ larutan dengan menggunakan kertas $\mathrm{pH}$.

25. Masukkan aquades ke dalam tabung reaksi 3 sebanyak 10 tetes dengan menggunakan pipet tetes kemudian hitung $\mathrm{pH}$ larutan dengan menggunakan kertas $\mathrm{pH}$.

26. Masukkan $\mathrm{NaOH}(0,01 \mathrm{M})$ ke dalam tabung reaksi 4 sebanyak 10 tetes dengan menggunakan pipet tetes kemudian hitung $\mathrm{pH}$ larutan dengan menggunakan kertas $\mathrm{pH}$.

27. Masukkan $\mathrm{NaOH}(0,1 \mathrm{M})$ ke dalam tabung reaksi 5 sebanyak 10 tetes dengan menggunakan pipet tetes kemudian hitung $\mathrm{pH}$ larutan dengan menggunakan kertas $\mathrm{pH}$.

28. Masukkan $\mathrm{H}_{2} \mathrm{O}_{2} 3 \%$ ke dalam masing-masing tabung reaksi sebanyak 15 tetes secara bersamaan, kemudian ukur tinggi gelembung semua tabung reaksi dalam jangka waktu 2 menit, kemudian catat pada data eksperimen.

29. Setelah praktikum selesai, bersihkan semua alat yang digunakan dalam praktikum. 


\section{Data Eksperimen}

Tabel Indikator 1 (kesegaran hati)

\begin{tabular}{|c|l|c|}
\hline Tabung & \multicolumn{1}{|c|}{ Eksperimen } & $\begin{array}{c}\text { Tinggi Gelembung } \\
(\mathrm{cm}) \text { dalam waktu 2 menit }\end{array}$ \\
\hline 1 & Hati segar $+\mathrm{H}_{2} \mathrm{O}_{2}$ & \\
\hline 2 & Hati yang telah direbus 5 menit $+\mathrm{H}_{2} \mathrm{O}_{2}$ & \\
\hline 3 & Hati yang telah direbus 15 menit $+\mathrm{H}_{2} \mathrm{O}_{2}$ & \\
\hline 4 & Hati yang setengah segar (dibiarkan 12 jam) $+\mathrm{H}_{2} \mathrm{O}_{2}$ & \\
\hline 5 & Hati yang busuk (dibiarkan 24 jam) & \\
\hline
\end{tabular}

Tabel indikator 2 (suhu)

\begin{tabular}{|c|l|c|}
\hline Tabung & \multicolumn{1}{|c|}{ Eksperimen } & $\begin{array}{c}\text { Tinggi Gelembung }(\mathrm{cm}) \\
\text { dalam waktu 2 menit }\end{array}$ \\
\hline 1 & Hati segar + air suhu $10 \mathrm{c}+\mathrm{H}_{2} \mathrm{O}_{2}$ & \\
\hline 2 & Hati segar + air suhu $20 \mathrm{c}+\mathrm{H}_{2} \mathrm{O}_{2}$ & \\
\hline 3 & Hati segar + air suhu $30 \mathrm{c}+\mathrm{H}_{2} \mathrm{O}_{2}$ & \\
\hline 4 & Hati segar + air suhu $40 \mathrm{c}+\mathrm{H}_{2} \mathrm{O}_{2}$ & \\
\hline 5 & Hati segar + air suhu $50 \mathrm{c}+\mathrm{H}_{2} \mathrm{O}_{2}$ & \\
\hline
\end{tabular}

Tabel indikator 3 (tingkat keasaman)

\begin{tabular}{|c|l|c|}
\hline Tabung & \multicolumn{1}{|c|}{ Eksperimen } & $\begin{array}{c}\text { Tinggi Gelembung }(\mathrm{cm}) \text { dalam } \\
\text { waktu 2 menit }\end{array}$ \\
\hline 1 & Hati segar $+\mathrm{HCl}(0,1 \mathrm{M})+\mathrm{H}_{2} \mathrm{O}_{2}$ & \\
\hline 2 & Hati segar $+\mathrm{HCl}(0,01 \mathrm{M})+\mathrm{H}_{2} \mathrm{O}_{2}$ & \\
\hline 3 & Hati segar + aquades $+\mathrm{H}_{2} \mathrm{O}_{2}$ & \\
\hline 4 & Hati segar $+\mathrm{NaOH}(0,01 \mathrm{M})+\mathrm{H}_{2} \mathrm{O}_{2}$ & \\
\hline 5 & Hati segar $+\mathrm{NaOH}(0,1 \mathrm{M})+\mathrm{H}_{2} \mathrm{O}_{2}$ & \\
\hline
\end{tabular}

\section{Pertanyaan}

1. Pada tabung nomor berapakah hati ayam yang tidak terjadi reaksi kimia? Mengapa demikian?

2. Pada perlakuan manakah pembentukan gelembung gas paling tinggi? Mengapa demikian?

3. Gas apakah yang terbentuk dari reaksi tersebut? Jelaskan berdasarkan hasil percobaan!

4. Faktor apakah yang memengaruhi kerja enzim katalase? Jelaskan berdasarkan hasil percobaan!

5. Bagaimana pengaruh kesegaran hati terhadap laju kerja enzim katalase? Buatlah dalam bentuk grafik berdasarkan data dari tabel yang anda peroleh!

6. Bagaimana pengaruh $\mathrm{pH}$ terhadap laju kerja enzim katalase? Buatlah dalam bentuk grafik 
berdasarkan data dari tabel yang anda peroleh!

7. Bagaimana pengaruh suhu terhadap laju kerja enzim katalase? Buatlah dalam bentuk grafik berdasarkan data dari tabel yang anda peroleh!

8. Bagaimana kesimpulan dari hasil percobaan yang Anda lakukan?

\section{SIMPULAN}

Setelah dilakukan analisis terhadap desain kegiatan laboratorium pada praktikum kerja enzim katalase, ditemukan bahwa desain kegiatan laboratorium yang diterbitkan oleh beberapa penerbit pada kurikulum ktsp, 2013 bahkan 2013 revisi belum memenuhi komponen DKL yang lengkap untuk meningkatkan keterampilan proses sains siswa dengan ditemukannya DKL yang beum menuntut siswa untuk menginterpretasi data ke dalam bentuk lain, membuat kesimpulan berdasarkan data yang didapat, serta memanipulasi beberapa variabel dalam percobaan. Sehingga perlu dilakukan rekonstruksi DKL berbasis keterampilan proses sains agar kegiatan praktikum dapat lebih bermakna bagi siswa sehingga konsep yang seharusnya dikuasai oleh siswa dapat tercapai dan dapat membangun keterampilanketerampilan dasar dalam kegiatan ilmiah.

\section{UCAPAN TERIMA KASIH}

Segala puji dan syukur serta kasih Tuhan yang maha esa sehingga penulis bisa menyelesaikan artikel ini. Terimakasih saya ucapkan kepada keluarga yang selalu mendukung dalam segala hal. Terkhusus terimakasih saya ucapkan kepada Bapak/lbu Dosen Pascasarjana Biologi FMIPA UPI Bapak Bambang Supriatno dan Ibu Sri Anggraeni yang sudah membimbing saya selama penyusunan artikel ini, begitu juga dengan teman satu kelas saya di Pendidikan Biologi Pascasarjana FMIPA UPI yang selalu mendukung saya sehingga artikel ini dapat saya selesaikan dengan baik. Dan pihak lain yang tidak bisa saya sebutkan satu-persatu atas bantuan dan dukungannya saya ucapkan terimakasih. Semoga artikel ini dapat bermanfaat untuk pembaca dalam meningkatkan pengetahuan tentang desain kegiatan laboratorium berbasis keterampilan proses sains yang menjadi suatu tuntutan dalam proses pembelajaran biologi serta keterampilan yang harus dimiliki oleh siswa dalam memahami ilmu sains.

\section{RUJUKAN}

Aisya, N. S. M., SaefudinSupriatno, B., \& Anggraeni, S. (2016). Penerapan Diagram Vee dalam Model Pembelajaran Inquiry Lab dan Group Investigation untuk Meningkatkan Kemampuan Literasi Kuantitatif Siswa Kelas VII pada Materi Pencemaran Lingkungan Application of Vee Diagram Learning Strategy Through Inquiry Lab and Gro. Proceeding Biology Education Conference, 13(1), 112-117.

Alexander, A., Rahayu, H. M., \& Kurniawan, A. D. (2018). Pengembangan Penuntun Praktikum Fotosintesis Berbasis Audio Visual Menggunakan Program Camtacia Studio di SMAN 1 Hulu Gurung. Jurnal Pendidikan Sains Indonesia, 6(2), 75-82. https://doi.org/10.24815/jpsi.v6i2.12075

Astuti, N. W., Yolida, B., \& Sikumbang, D. (2019). Hubungan Praktikum dan Keterampilan Proses Sains Terhadap Hasil Belajar Materi Ekosistem. Jurnal Jurnal Bioterdidik, 7(5), 54.

Elvanisi, A., Hidayat, S., \& Fadillah, E. N. (2018). Analisis keterampilan proses sains siswa sekolah menengah atas Skills analysis of science process of high school students. Jurnal Inovasi Pendidikan IPA, 4(20), 245-252. https://journal.uny.ac.id/index.php/jipi/article/view/21426/12225

Koirala, K. P. (2019). Effectiveness of Practical Work on Students' Achievement in Science at Secondary Level in Gorkha District Nepal. Journal of Advances in Education Research, 4(4), 139-147. https://doi.org/10.22606/jaer.2019.44001

Laelasari, I., Sari, N. E., \& Nuhaya, N. (2019). Strategi yang Dapat Dikembangkan Dalam Pembelajaran 
Laboratorium Biologi. Thabiea: Journal of Natural Science Teaching, 2(1), 29. https://doi.org/10.21043/thabiea.v2i1.4815

Laila Puspita. (2019). Pengembangan modul berbasis keterampilan proses sains sebagai bahan ajar dalam pembelajaran biologi Module development based on science process skills as teaching materials in biological learning. Jurnal Inovasi Pendidikan IPA, 5(1), 79-87.

Mirawati, B., \& Royani, I. (2019). Pengembangan LKS Biologi SMA Berbasis Praktikum dengan Model Pembelajaran Langsung untuk Meningkatkan Keterampilan Proses Sains Siswa. Jurnal Penelitian Dan Pengkajian IImu Pendidikan: E-Saintika, 3(2), 88. https://doi.org/10.36312/e-saintika.v3i2.152

Nisa, U. M. (2017). Metode Praktikum untuk Meningkatkan Pemahaman dan Hasil Belajar Siswa Kelas V MI YPPI 1945 Babat pada Materi Zat Tunggal dan Campuran. Journal Biology Education, 14(1), 62-68.

Royani, I., Mirawati, B., \& Jannah, H. (2018). Pengaruh Model Pembelajaran Langsung Berbasis Praktikum Terhadap Keterampilan Proses Sains dan Kemampuan Berpikir Kritis Siswa. Prisma Sains : Jurnal Pengkajian IImu Dan Pembelajaran Matematika Dan IPA IKIP Mataram, 6(2), 46. https://doi.org/10.33394/j-ps.v6i2.966

Sasanti, M., Hartini, S., \& Mahardika, A. I. (2017). Pengembangan LKS Dengan Model IDL Untuk Melatihkan Keterampilan Proses Sains Pada Pokok Bahasan Listrik Dinamis Di SMAN 5 Banjarmasin. Berkala IImiah Pendidikan Fisika, 5(1), 46. https://doi.org/10.20527/bipf.v5i1.2815

Septaria, K., Dewanti, B. A., \& Habibbulloh, M. (2019). Implementasi Metode Pembelajaran Spot Capturing Pada Materi Pemanasan Global untuk Meningkatkan Keterampilan Proses Sains. Prisma Sains : Jurnal Pengkajian IImu Dan Pembelajaran Matematika Dan IPA IKIP Mataram, 7(1), 27. https://doi.org/10.33394/j-ps.v0i0.1379 